\title{
FAKTOR RISIKO HIPERTENSI PADA SISWA SMU ADABIAH DI KOTA PADANG
}

\author{
Delmi Sulastri, Sidhi \\ Bagian Ilmu Gizi Fakultas Kedokteran Universitas Andalas \\ email : delmisulastri@yahoo.com
}

\begin{abstract}
Abstrak
Hipertensi pada anak dan remaja sudah merupakan masalah kesehatan mesyarakat yang ada di Indonesia maupun di beberapa negara yang ada di dunia. Hampir 95\% kasus hipertensi tidak diketahui penyebabnya atau disebut hipertensi esensial. Beberapa faktor risiko diduga berhubungan dengan peningkatan prevalensi hipertensi ini.

Telah dilakukan penelitian dengan desain cross sectional study pada siswa SMU Adabiah yang berusia antara 15 tahun sampai 18 tahun, bertujuan untuk melihat hubungan faktor risiko riwayat keturunan, obesitas, aktifitas fisik dan kebiasaan merokok dengan kejadian hipertensi. Sampel sebanyak 61 orang, kemudian dilakukan wawancara mengenai karakteristik, riwayat keturunan, aktifitas fisik dan kebiasaan merokok serta pemeriksaan tekanan darah dan antropometri. Data yang diperoleh selanjutnya dianalisis menggunakan uji chi-square serta ditampilkan dalam bentuk tabel, gambar dan narasi.

Hasil penelitian ini adalah $66.7 \%$ siswa mengalami obese, $20.7 \%$ mempunyai keturunan hipertensi, 30\% dengan aktifitas fisik rendah dan $33.3 \%$ mempunyai kebiasaan merokok mengalami hipertensi.Tidak didapat hubungan antara obesitas, riwayat keturunan dan aktifitas fisik dengan kejadian hipertensi dan terdapat hubungan antara merokok dengan kejadian hipertensi $(\mathrm{p}=0.033)$.

Perlu dilakukan kebijakan yang mengatur tentang peraturan merokok pada anak remaja.

Kata kunci : Hipertensi, Riwayat keturunan dan Obesitas
\end{abstract}

\begin{abstract}
Hypertension in children and adolescents is a health problem of the community is in Indonesia as well as in several countries of the world. Almost $95 \%$ of the hypertension cases have no cause yet identified or it can be referred to as essential hypertension. Some of the risk factors associated with an increased prevalenceofhypertension.

A research has be made based on cross sectional study study with a cross sectional study Adabiah high school students aged between 15 years to 18 years. The aims to examine the relationship of risk factors history of heredity, obesity, physical activity and smoking habits with the incidence of hypertension. Sample of 61 people were interviewed about the characteristics, history of heredity, physical activity and smoking habits and blood pressure and anthropometry. The data
\end{abstract}


obtained were then analyzed using the chi-square test and displayed in the form of tables, figuresandnarratives.

The results of this study were $66.7 \%$ of students had obese, $20.7 \%$ had a descendants of hypertension, 30\% with low physical activity, and $33.3 \%$ having ever smoked had hipertensi.Tidak obtained relationship between obesity, a history of heredity and physical activity with the incidence of hypertension and the relationship between smoking with the incidence of hypertension $(p=0033)$. There needs to be policy regarding smoking regulations in adolescents. Key word : Hypertension, Heredity and Obesity 


\section{Pendahuluan}

Hipertensi merupakan suatu penyakit yang ditandai dengan peningkatan tekanan darah di atas nilai normal, yaitu nilai sistolik $\geq 140 \mathrm{mmHg}$ dan atau diastolik $\geq 90 \mathrm{mmHg}^{\left({ }^{(1)}\right.}$ Penyakit ini dapat memberi gejala berlanjut untuk suatu target organ, seperti otak, pembuluh darah dan otot jantung. Saat ini hipertensi sudah menjadi masalah utama kesehatan masyarakat di Indonesia maupun di beberapa negara di dunia. ${ }^{(2)}$ Hampir separoh penduduk dewasa Eropa dan seperempat penduduk dunia menderita hipertensi. Data dari The National Health and Nutrition Examination Survey (NHNES) menunjukkan dari tahun 1999 - 2000 insiden hipertensi pada orang dewasa adalah $29 \%-32 \%$, ini berarti bahwa terdapat 58 - 65 juta orang menderita hipertensi di Amerika dan terjadi peningkatan 15 juta dari data tahun 1988 - 1991 . $^{(3)}$

Prevalensi hipertensi di seluruh dunia sekitar $15 \%$ - 20\% sedangkan di Asia sudah mencapai 8\% - 18\%. Pada tahun 2025 diperkirakan terjadi kenaikan kasus hipertensi sekitar $80 \%$, yaitu dari 639 juta kasus di tahun 2000, menjadi 1,15 milyar kasus pada tahun 2025. Peningkatan tersebut terutama terjadi di negara sedang berkembang. Prediksi ini berdasarkan angka penderita hipertensi dan pertambahan penduduk saat ini. ${ }^{(3,4)}$ Data tentang prevalensi hipertensi di Indonesia telah banyak dilaporkan tetapi karena Indonesia merupakan negara kepulauan dengan banyak suku bangsa, sehingga sulit untuk mendapatkan prevalensi hipertensi secara pasti. Beberapa penelitian dapat menemukan prevalensi hipertensi di Indonesia berkisar antara $17 \%$ sampai $21 \%$, sedangkan menurut laporan Depkes RI (2007) prevalensi hipertensi di Indonesia adalah $29,8 \%$. ${ }^{(5)}$ Angka-angka ekstrim rendah dapat ditemukan di Ungaran Jawa Tengah yaitu 1,8\%, Lembah Baliem Pegunungan Jaya Wijaya Irian Jaya $0,6 \%$ dan ekstrim tinggi di Talang Sumatera Barat 17,8\%. Wanita mempunyai prevalensi lebih tinggi dari pada pria. ${ }^{(6,2)}$ Prevalensi hipertensi di Sumatera Barat juga cenderung meningkat. Pada tahun 1977 prevalensi hipertensi hanya $7,3 \%{ }^{(6)}$ kemudian pada tahun 2007, hasil riset kesehatan dasar yang dilakukan Departemen Kesehatan RI melaporkan bahwa prevalensi hipertensi di Sumatera Barat sudah mencapai $31,2 \%$.

\section{Peningkatan}

prevalensi hipertensi tidak saja terjadi pada orang dewasa, tetapi juga pada anak dan remaja. Beberapa penelitian membuktikan bahwa hipertensi pada orang dewasa telah diawali oleh peningkatan tekanan darah individu tersebut mulai dari masa masih anak-anak atau remaja. Hipertensi pada anak dan remaja didefenisikan sebagai rerata tekanan darah sistolik dan atau diastolik $\geq$ persentil 95 sesuai dengan jenis kelamin, usia dan tinggi badan pada $\geq 3$ kali pengukuran. ${ }^{(7)}$

Saat ini prevalensi hipertensi pada anak dan remaja tampak semakin meningkat, diperkirakan antara 1\%-2\%. Hal ini kemungkinan berkaitan dengan meningkatnya prevalensi obesitas pada anak dan juga meningkatnya kepedulian kita terhadap penyakit ini.Peningkatan prevalensi hipertensi tidak saja terjadi di dunia, berdasarkan data Riset Kesehatan Daerah tahun 2007 didapatkan prevalensi hipertensi di Indonesia sudah mencapai $9 \% .{ }^{(7)}$

Sembilan puluh lima persen penyakit hipertensi tidak diketahui penyebabnya dan dikenal sebagai hipertensi primer atau esensial. Terdapat beberapa faktor risiko yang erat kaitannya dengan kejadian hipertensi. Faktor risiko terbagi menjadi 
dua yang dapat dimodifikasi dan tidak dapat dimodifikasi. Faktor risiko yang tidak dapat dimodifikasi antara adalah faktor keturunan sedangkan yang tidak dapat dimodifikasi antara lain obesitas, aktifitas fisik dan kebiasaan merokok.

Penelitian yang dilakukan oleh Framingham Heart Study menunjukkan risiko kejadian hipertensi meningkat 2,6 kali pada subyek laki-laki obesitas dan meningkat 2,2 kali pada subyek wanita obesitas dibandingkan subyek dengan berat badan normal. Hasil yang sama juga dilaporkan oleh Salam (2010) pada siswa SMP di Serang, terdapat hubungan yang bermakna antara riwayat keturunan dan obesitas dengan kejadian hipertensi. ${ }^{(10)}$ Penelitian Liputo dkk menunjukkan sebaran penderita Sindrom Metabolik (Hipertensi dan Obesitas) berdasarkan jenis kelamin, lebih banyak dialami oleh perempuan $(26,8 \%)$ dan hanya $6,3 \%$ pada responden laki-laki. ${ }^{(11)} \quad$ Penelitian Bowman (2008) mengatakan bahwa terdapat hubungan antara kebiasaan merokok dengan kejadian hipertensi, hal ini dibuktikan dari sebagian besar penderita hipertensi adalah perokok berat. Zinner dalam Page (1983), bahwa tekanan darah pada anak-anak dengan orang tua yang hipertensi lebih tinggi bila dibandingkan dengan tekanan darah pada anak-anak dengan orang tua yang tidak hipertensi. ${ }^{(12)}$

\section{METODE PENELITIAN}

\section{Desain dan Lokasi Penelitian}

Penelitian ini adalah deskriptif analitik dengan desain cross sectional study, dan dilakukan di Sekolah Menengah Umum (SMU) Ababiah di kota Padang Provinsi Sumatera Barat.

Populasi dan sampel : Populasi adalah semua Siswa SMU Adabiah yang berumur 15 tahun sampai 18 tahun (Kelas X dan XI) di Kota Padang Prov.
Sumatera Barat. Sampel diambil dengan menggunakan rumus didapatkan jumlah sampel sebesar 61 orang.

Sampel diambil dengan cara proporsional untuk menentukan jumlah siswa yang mewakili tiap-tiap kelas, sedangkan pengambilan sampel di tiaptiap kelas dengan metoda sistematik random sampling.

\section{Pengumpulan data}

Data karakteristik, riwayat keturunan, aktifitas fisik serta kebiasaan merokok diperoleh melalui wawancara menggunakan kuesioner sedangkan pengukuran tekanan darah dengan menggunakan sfigmomanometer merk NOVA, pengukuran Berat Badan serta Tinggi Badan menggunakan timbangan berat badan dan microtoise dengan ketelitian $0.01 \mathrm{~mm}$

\section{Analisis data}

Analisis univariat, untuk melihat distribusi data masing - masing variabel dan kemudian disajikan dalam bentuk tabel dan diagram. Data terdiri dari karakteristik, kejadian hipertensi, riwayat keturunan, aktifitas fisik dan kebiasaan merokok.

Analisis bivariat, untuk melihat hubungan antara variabel dependen dengan variabel independen dengan menggunakan chi-square dengan derajat kepercayaan $95 \%$.

\section{HASIL PENELITIAN}

SMU Adabiah Padang berlokasi di jalan Perintis Kemerdekaan Kecamatan Padang Timur Kota padang. SMU Adabiah mempunyai 1 orang kepala Sekolah, 4 orang wakil kepala sekolah, 45 orang guru, 14 tenaga tata usaha dan 5 orang tenaga satpam. Fasilitas sekolah meliputi ruang belajar, ruang laboratorium, perpustakaan, masjid, lapangan olahraga dan kantin. 


\section{Karakteristik responden}

Responden laki-laki sebanyak 24 siswa dan responden perempuan sebanyak 37 siswa. Usia rata-rata umur responden adalah 16,36 $\pm 0,913$ tahun, nilai tengah umur responden adalah 16 tahun dan umur terbanyak adalah 17 tahun. Umur termuda adalah 15 tahun dan umur tertua adalah 18 tahun.

Dari pengumpulan data yang telah dilakukan di SMU Adabiah Padang dan dilakukan analisis univariat didapatkan gambaran sebagai berikut:

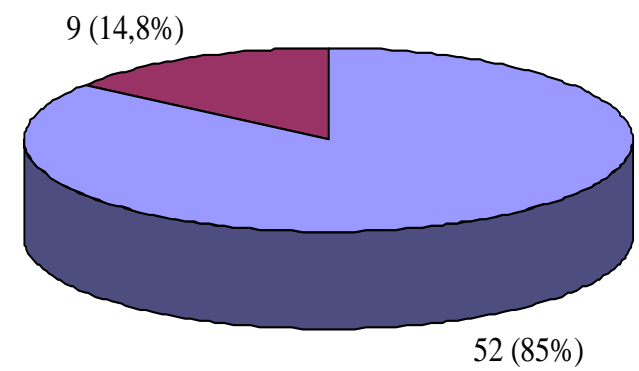

$\square$ Tidak hipertensi $\square$ Hipertensi

\section{Gambar 1. Distribusi Frekuensi Responden Berdasarkan Kejadian Hipertensi di SMU Adabiah Padang}

Pada Gambar 1, dapat Tabel 1. Distribusi Frekuensi Obesitas, diketahui bahwa dari seluruh Riwayat Keturunan, Aktifitas Fisik dan responden yang telah dilakukan Kebiasaan Merokok Pada Responden pengukuran tekanan darah maka didapat Penelitian

hasil bahwa kejadian hipertensi ditemukan sebanyak 9 orang $(14,8 \%)$. Kemudian dilakukan pengukuran antropometri dan wawancara riwayat keturunan, aktifitas fisik dan kebiasaan merokok dengan menggunakan kuesioner. Dari pengumpulan data ini diperoleh hasil sebagai berikut :

\begin{tabular}{|c|c|c|}
\hline \multirow{2}{*}{ Faktor Risiko } & \multicolumn{2}{|l|}{$\begin{array}{l}\text { Jumlah } \\
\text { Responden }\end{array}$} \\
\cline { 2 - 3 } & f & \% \\
\hline Obesitas & & \\
Tidak obesitas & 58 & 95.1 \\
Obesitas & 3 & 4.9 \\
\hline Riwayat & 32 & 52.5 \\
Keturunan & 32 & 47.5 \\
Tidak ada & 29 & \\
Ada & & \\
\hline Aktifitas Fisik & 30 & 49.2 \\
Rendah \\
Tinggi & 31 & 50.8 \\
\hline Kebiasaan & & \\
Merokok & 46 & 75.4 \\
Tidak & 15 & 24.6 \\
Merokok & & \\
& & \\
\hline
\end{tabular}


Pada Tabel 1 di atas dapat dilihat bahwa kejadian obesitas hanya ditemukan pada 3 orang responden $(4.9 \%)$, hampir separoh memiliki riwayat keturunan hipertensi (47.5\%). Responden yang memiliki aktifitas tinggi hampir sama banyak dengan yang memiliki aktifitas rendah yaitu $49.2 \%$ dan $50.8 \%$, sedangkan kebiasaan merokok ditemukan sebanyak 15 orang (24.6\%).
Tabel 2. Distribusi Frekuensi Responden yang Merokok Berdasarkan Jumlah Merokok Per Hari di SMU Adabiah Padang

\begin{tabular}{ccc}
\hline \multirow{2}{*}{ Jumlah rokok perhari } & \multicolumn{2}{l}{ Jumlah } \\
& responden \\
& f & \% \\
\hline$<5$ batang/hari & 13 & 86.7 \\
6 - 20 batang/hari & 2 & 13.3 \\
\hline Jumlah & $\mathbf{1 5}$ & $\mathbf{1 0 0}$ \\
\hline
\end{tabular}

Dari Tabel 2, diketahui bahwa sebagian besar responden menghisap rokok $<5$ batang/hari yaitu 13 orang $(86,7 \%)$ dan hanya 2 orang $(13,3 \%)$ yang menghisap rokok 6-20 batang/hari.

Tabel 3. Distribusi Responden Menurut Kejadian Hipertensi Berdasarkan Obesitas di SMU Adabiah Padang

\begin{tabular}{|c|c|c|c|c|c|c|c|c|}
\hline \multirow{3}{*}{\multicolumn{2}{|c|}{ Faktor Risiko }} & \multicolumn{4}{|c|}{ Kejadian Hipertensi } & \multicolumn{2}{|c|}{ Total } & \multirow{4}{*}{$\begin{array}{c}\begin{array}{c}\mathbf{p} \\
\text { value }\end{array} \\
0.054\end{array}$} \\
\hline & & \multicolumn{2}{|c|}{ Tidak } & \multicolumn{2}{|c|}{$\mathbf{Y a}$} & \multirow{3}{*}{$\begin{array}{c}\mathbf{f} \\
58\end{array}$} & \multirow{2}{*}{$\%$} & \\
\hline & & \multirow{3}{*}{$\begin{array}{c}\mathbf{f} \\
51 \\
1\end{array}$} & \multirow{2}{*}{$\begin{array}{c}\% \\
87.9\end{array}$} & \multirow{2}{*}{$\frac{\mathbf{f}}{7}$} & \multirow{2}{*}{$\frac{\%}{12.1}$} & & & \\
\hline Obesitas & Tdk obese & & & & & & 100 & \\
\hline & obese & & 33.1 & 2 & 66.7 & 3 & 100 & \\
\hline \multirow{2}{*}{$\begin{array}{l}\text { Riwayat } \\
\text { Keturunan }\end{array}$} & Tidak ada & 29 & 90.6 & 3 & 9.4 & 32 & 100 & \multirow[t]{2}{*}{0.287} \\
\hline & Ada & 23 & 79.3 & 6 & 20.7 & 29 & 100 & \\
\hline \multirow[t]{2}{*}{ Aktifitas Fisik } & Tinggi & 25 & 80.6 & 6 & 19.4 & 31 & 100 & \multirow[t]{2}{*}{0.473} \\
\hline & Rendah & 27 & 90 & 3 & 10 & 30 & 100 & \\
\hline \multirow[t]{2}{*}{ Kebiasaan Merokok } & Tidak & 42 & 91.3 & 4 & 8.7 & 46 & 100 & \multirow[t]{2}{*}{0.033} \\
\hline & Merokok & 10 & 66.7 & 5 & 33.3 & 15 & 100 & \\
\hline
\end{tabular}

Pada Tabel 3 dapat dilihat menunjukkan tidak terdapat hubungan bahwa kejadian hipertensi pada siswa bermakna antara riwayat keturunan yang mengalami obesitas sebesar hipertensi dengan kejadian hipertensi ( $p$ $66,7 \%$, lebih tinggi dibandingkan $=0,287$ ).

dengan siswa yang tidak obesitas yaitu sebesar $12,1 \%$. Hasil uji statistik, tidak terdapat hubungan bermakna antara obesitas dengan kejadian hipertensig ( $p$ $=0,054$ ).

Aktivitas fisik merupakan salah satu faktor risiko. Pada penelitian ini siswa dengan aktivitas fisik tinggi sebesar 19,4\%, lebih tinggi dibanding pada siswa dengan aktivitas fisik rendah Hipertensi pada siswa yang sebesar $10 \%$. Hasil uji statistik, tidak ada riwayat keturunan hipertensi 20,7\%, ada hubungan bermakna antara aktivitas lebih tinggi dibanding pada siswa yang fisik dengan kejadian hipertensi $(\mathrm{p}=$ tidak ada riwayat keturunan hipertensi 0,473).

sebesar 9,4\%. Hasil uji statistik 
Kebiasaan merokok sudah ditemukan pada remaja. Siswa yang memiliki kebiasaan merokok sebesar $33,3 \%$, lebih tinggi dibanding pada siswa yang tidak merokok sebesar $8,7 \%$. Hasil uji statistik terdapat hubungan bermakna antara merokok dengan kejadian hipertensi $(\mathrm{p}=0,033)$.

\section{Diskusi}

\section{Kejadian hipertensi}

Pada penelitian diperoleh hasil bahwa siswa dengan hipertensi sebanyak $14,8 \%$. Hasil penelitian ini lebih tinggi bila dibandingkan dengan penelitian Aminudin (2003) di Makasar siswa hipertensi sebanyak 4.24\%. Hasil penelitian ini hampir sama dengan data pada SKRT 2001 dimana prevalensi hipertensi pada golongan umur 15-24 tahun sebanyak 16\%. Penelitian Boedi Darmojo (1995) di Jakarta, mendapatkan prevalensi hipertensi sebanyak 16,9\%. Menurut Harrldberg (1985) dalam Aminudin (2003), prevalensi hipertensi pada anak-anak dan remaja dari berbagai studi yang berbeda berkisar 1-11\%. Perbedaan hasil tersebut di atas mungkin disebabkan oleh perbedaan standar hipertensi yang digunakan. ${ }^{(13,14)}$

Dari bukti yang berkembang, ternyata bahwa hipertensi primer telah ditemukan pada usia muda. Serangan jantung dan stroke berhubungan dengan tekanan darah tinggi pada masa anakanak dan remaja. Beberapa penelitian pada dewasa muda dengan tekanan darah tinggi menunjukkan bahwa kebanyakan dari mereka mempunyai riwayat tekanan darah tinggi pada masa anak-anak. Untuk jangka panjang, resiko-resiko kesehatan untuk hipertensi pada anak-anak dan remaja seperti obesitas dapat menjadi hal yang penting. ${ }^{(15)}$

\section{Hubungan obesitas dengan kejadian hipertensi}

Pada penelitian ini diperoleh frekuensi obesitas sebanyak 4,9\%. Hasil penelitian ini lebih rendah bila dibandingkan penelitian Aminudin (2003) di Makasar sebanyak 6,84\%, juga lebih rendah dibandingkan dengan di Singapura sebanyak 5,4\%, dan jauh lebih rendah bila dibandingkan dengan Amerika dan Eropa masing-masing sebanyak $20 \%$ dan 25\%. Perbedaan hasil tersebut di atas mungkin disebabkan oleh perbedaan gaya hidup serta standar untuk obesitas yang digunakan. ${ }^{(14)}$

Obesitas telah dilaporkan sebagai salah satu faktor resiko bagi berkembangnya hipertensi pada anakanak dan remaja. Prevalensi obesitas dilaporkan bervariasi di berbagai negara. Perbedaan dari prevalensi obesitas ini karena perbedaan kesejahteraan masyarakat, gaya hidup dan faktor-faktor lainnya. ${ }^{(14)}$

Jumlah lemak tubuh akan meningkat sesuai dengan peningkatan umur. Oleh karena itu penderita gizi lebih sering ditemukan pada orang dewasa. Garrow seperti yang dikutip oleh Mourbas, menyatakan bahwa prevalensi obesitas (IMT>30) meningkat terus sampai umur 50 tahun untuk pria, sedangkan wanita sampai umur 65 tahun. Demikian juga dengan penelitian di Austria yang menemukan bahwa kejadian gizi lebih banyak terjadi pada umur di atas 40 tahun dibandingkan dibawah 40 tahun. ${ }^{(16)}$

Kejadian hipertensi pada siswa yang obese sebanyak $66,7 \%$. Hasil uji statistik menyimpulkan bahwa tidak ada hubungan bermakna antara obesitas dengan kejadian hipertensi $(\mathrm{P}>0,05)$. Namun jika dilihat dari proporsinya, pada penelitian ini hipertensi pada siswa yang obese sebanyak $66,7 \%$, jauh lebih tinggi dari pada siswa yang tidak 
obese yaitu sebanyak $12,1 \%$. Frekuensi hipertensi pada remaja obese pada penelitian ini hampir sama dengan penelitian Dietz (1997) sebanyak 60\%, tetapi lebih tinggi dari penelitian Aminudin (2003) sebanyak 30,6\%. ${ }^{(14)}$

Dari studi prospektif longitudinal didapat penurunan resiko hipertensi paralel dengan menurunnya berat badan. Sebaliknya peningkatan resiko hipertensi paralel dengan meningkatnya berat badan. Hubungan antara hipertensi dengan obesitas belum diketahui secara pasti, namun terbukti bahwa daya pompa jantung dan sirkulasi volume darah penderita obesitas dengan hipertensi lebih tinggi daripada penderita hipertensi dengan berat badan normal. ${ }^{(17)}$

Penurunan berat badan pada obesitas akan memberikan efek penurunan volume darah, penurunan cardiac output, penurunan resistensi vaskuler perifer, penurunan resistensi insulin, penurunan aktifitas simpatis / system renin angiotensin yang berakibat pada penurunan tekanan darah. Tekanan darah dan IMT pada anak secara konsisten tampaknya merupakan dua prediktor yang paling kuat untuk nilai tekanan darah pada usia dewasa. ${ }^{(17,18)}$

Studi-studi epidemiologi mengenai tekanan darah pada masyarakat mencatat adanya hubungan yang signifikan antara tekanan darah dengan massa tubuh dan antara hipertensi dengan obesitas. Studi-studi ini menunjukkan hubungan antara tekanan darah dan massa tubuh lebih tergantung pada total massa tubuh dan tidak ada hubungan dengan komposisi tubuh. ${ }^{(19)}$

Hal ini mungkin tidak berlaku bagi anak-anak dan remaja. Prineas dalam Page (1983), menemukan bahwa pada anak-anak dan remaja obese, tekanan darah meningkat sesuai dengan tebal lipatan kulit dan tidak tergantung pada IMT. Tebal lipatan kulit triseps korelasinya terhadap total lemak tubuh lebih baik dibandingkan dengan IMT, menunjukkan bahwa tebal lipatan kulit mungkin suatu pengukuran yang lebih sahih untuk lemak tubuh. ${ }^{(18,19)}$ Hal ini mungkin yang menyebabkan tidak ada hubungan obesitas dengan hipertensi pada penelitian ini.

\section{Hubungan keturunan dengan kejadian hipertensi}

Pada penelitian ini diperoleh data hipertensi pada siswa yang ada riwayat hipertensi sebanyak 20,7\%, lebih tinggi dibanding pada siswa yang tidak ada riwayat hipertensi sebanyak 9,4\%. Hasil uji statistik menyimpulkan bahwa tidak ada hubungan bermakna antara keturunan dengan kejadian hipertensi $(P>0,05)$.

Menurut Zinner dalam Page (1983), bahwa tekanan darah pada anak-anak dengan orang tua yang hipertensi lebih tinggi bila dibandingkan dengan tekanan darah pada anak-anak dengan orang tua yang tidak hipertensi. Kecenderungan untuk mengidap tekanan darah tinggi dapat diturunkan dalam keluarga, tetapi ada banyak variasi. Semakin dekat hubungan darah dengan seseorang yang mengidap tekanan darah tinggi, semakin besar kemungkinan orang tersebut untuk mengidap tekanan darah tinggi. ${ }^{(20,19)}$

Bila riwayat hipertensi didapat pada kedua orang tua, maka dugaan hipertensi essensial akan sangat besar. Demikian pula dengan kembar monozygot (satu sel telur), bila salah satunya adalah penderita hipertensi. ${ }^{(21)}$

Pada penelitian ini tidak adanya hubungan keturunan dengan hipertensi mungkin disebabkan oleh karena kurang dekatnya faktor genetik dengan seseorang yang mengidap tekanan darah tinggi. Dari 29 siswa 
yang mempunyai riwayat hipertensi dalam keluarganya, hanya 2 siswa $(6,9 \%)$ yang kedua orang tuanya menderita hipertensi, selebihnya bervarisai antara ibu, ayah, kakek atau nenek saja.

Hasil penelitian ini menunjukkan bahwa siswa yang tidak ada riwayat hipertensi sedikit lebih banyak yaitu $52,5 \%$ dari pada siswa yang ada riwayat hipertensi yaitu sebanyak 47,5\%, banyaknya siswa dengan riwayat hipertensi pada keluarga ini mungkin berhubungan dengan besarnya prevalensi hipertensi di Kota Padang sebanyak $29,5 \%$. $^{(22)}$

\section{Hubungan aktifitas fisik dengan kejadian hipertensi}

Hasil penelitian menunjukkaan bahwa siswa mempunyai aktivitas fisik yang tinggi yaitu sebanyak 50,8\%, sedang siswa dengan aktivitas fisik yang rendah sebanyak 49,2\%. Hasil penelitian ini berbeda dengan penelitian Agustina (1995) di Jakarta dimana sebagian besar siswa mempunyai aktivitas fisik sedang yaitu sebanyak $70 \%$, sedang siswa dengan aktivitas fisik tinggi dan rendah masing-masing sebanyak $3,3 \%$ dan $26,7 \%$. $^{(23)}$ Pada penelitian ini diperoleh data hipertensi pada siswa dengan aktivitas fisik tinggi sebanyak $19,4 \%$, lebih tinggi dibanding pada siswa dengan aktivitas fisik rendah sebanyak 10\%. Hasil uji statistik menyimpulkan bahwa tidak ada hubungan bermakna antara aktivitas fisik dengan kejadian hipertensi ( $\mathrm{P}>$ $0,05)$.

Setiap anak maupun remaja membutuhkan latihan jasmani. Melalui latihan jasmani secara teratur akan meningkatkan daya tahan, kekuatan otot dan kesegaran jasmani. Latihan jasmani juga mempengaruhi faktor resiko penyakit kardiovaskuler dan tekanan darah pada waktu istirahat. Selain itu juga dapat menurunkan tekanan darah pada remaja dengan hipertensi ringan. ${ }^{(23)}$

Perbedaan jenis, frekuensi dan itensitas gerak badan serta ada atau tidaknya penurunan berat badan ikutan dapat menyokong variabilitas respon tekanan darah terhadap latihan. Peneltian Stamler yang dikutip oleh Leon dan Blackburn memperlihatkan manfaat jangka panjang gerak badan bersama dengan perubahan kebiasaan makan dan penurunan berat badan dalam mengendalikan hipertensi ringan yang telah ada. ${ }^{(24)}$

Pada penelitian ini tidak adanya hubungan aktivitas fisik dengan hipertensi mungkin disebabkan oleh karena hanya sebagian kecil siswa yang melakukan kegiatan olahraga secara teratur. Alokasi waktu sebagian besar siswa digunakan untuk kegiatan rutin seperti pekerjaan rumah tangga, belajar, dan menonton televisi. Disamping itu pada penelitian ini kebiasaan makan dari responden tidak diteliti, padahal manfaat jangka panjang gerak badan bersama dengan perubahan kebiasaan makan dan penurunan berat badan penting dalam mengendalikan hipertensi ringan yang telah ada.

\section{Hubungan merokok dengan kejadian hipertensi}

Hasil penelitian menunjukkan sebagian besar siswa tidak merokok yaitu sebanyak $75,4 \%$ dan siswa yang merokok sebanyak 24,6\%. Dari 24,6\% siswa yang merokok, $86,7 \%$ merupakan perokok ringan dan 13,3\% merupakan perokok sedang. Bila dilihat dari jenis kelamin, maka didapatkan $54,2 \%$ siswa laki-laki merokok dan $5,4 \%$ siswa perempuan merokok.

Mourbas (1997), di Padang yang melakukan penelitian pada orang dewasa mendapat angka 14,83\% yang merokok. SUSENAS tahun 2001 
didapatkan jumlah mulai merokok pada umur 15-19 tahun sebanyak 59,1\%. Bila dilihat dari jenis kelamin penelitian ini tidak jauh berbeda dengan penelitian Boedi Darmojo (1995), di Jakarta dimana laki-laki yang merokok sebanyak $56,8 \%$ dan pada perempuan sebanyak 6,2\%. Data WHO menyebutkan bahwa 59\% laki-laki dan $3,7 \%$ perempuan Indonesia adalah perokok. ${ }^{(16,25)}$

Pada penelitian ini, diketahui bahwa hipertensi pada siswa merokok sebanyak $33.3 \%$, lebih tinggi dibanding pada siswa yang tidak merokok sebanyak $8.7 \%$. Hasil uji statistik menyimpulkan bahwa ada hubungan bermakna antara merokok dengan kejadian hipertensi $(\mathrm{P}<0,05)$.

Merokok tinggi nikotin menyebabkan peningkatan tekanan darah sistolik dan tekanan darah diastolik. Nikotin menyebabkan kenaikan tekanan arteri dan denyut jantung. Merokok menaikkan tekanan darah secara akut dan tekanan darah akan sedikit berubah bila orang berhenti merokok. ${ }^{(26)}$

Hal ini mungkin berhubungan dengan fakta perokok lebih ringan 5-10 $\mathrm{kg}$ daripada bukan perokok dengan umur, tinggi badan dan jenis kelamin yang sama. Bila mereka berhenti merokok seringkali berat badan akan meningkat. Turunnya tekanan darah akibat tidak merokok dan naiknya tekanan darah karena peningkatan berat badan tampaknya berimbang satu sam lain. Sebaliknya kematian karena hipertansi lebih lazim dialami perokok daripada pasien hipertensi yang tidak merokok. ${ }^{(25)}$

Disamping sebagai faktor resiko utama pada semua tingkatan hipertensi, rokok yang mengandung nikotin akan meningkatkan tekanan darah. Seseorang yang merokok sebanyak 2 batang, tekanan darahnya meningkat $10-8 \mathrm{mmHg}$ selama 15 menit. Kebiasaan merokok 1,5-2 bungkus perhari, tekanan darah akan meningkat selama 7-10 jam dalam 1 hari. Pengurangan kebiasaan merokok akan dapat menurunkan tekanan darah tinggi. ${ }^{(26)}$

Biasanya remaja mulai merokok karena pengaruh dari teman untuk tampak lebih gagah. Dorongan tambahan dapat berasal dari orang tua dan media massa. Kebanyakan dari mereka menyadari bahaya dari merokok. ${ }^{(25)}$

\section{Kesimpulan}

Dari semua data yang telah dilakukan analisis, maka dapat diambil kesimpulan bahwa $66.7 \%$ siswa yang obese, $20.7 \%$ mempunyai keturunan hipertensi, 30\% dengan aktifitas fisik rendah dan $33.3 \%$ mempunyai kebiasaan merokok mengalami hipertensi. Tidak didapat hubungan antara obesitas, riwayat keturunan dan aktifitas fisik dengan kejadian hipertensi dan terdapat hubungan antara merokok dengan kejadian hipertensi

\section{KEPUSTAKAAN}

1. National Institutes of Health, National Heart, Lung, and Blood Intitute. 2003. The seventh report of the joint national committe on prevention, detection, evaluation and treatment of high blood pressure (JNC VII). Available at: http://www.nhlbi.nih.gov/guidel ines/hypertension/jn7full.pdf,

2. Armilawaty, Amalia $\mathrm{H}$ dan Amiruddin, 2007. Hipertensi dan faktor risikonya dalam Kajian epidemiologi.Bagian Epidemiologi. FKM UNHAS. 
3. Woodwell DA, 2000. Advance data from vital and health statistics, in National ambulatory Medical Survey. National Center for Health Statistics Hypertension 44 : 419.

4. Hadi H, 2005. Beban Ganda Masalah Gizi dan Implikasinya Terhadap Kebijakan Pembangunan Kesehatan Nasional. Pidato Pengukuhan Jabatan Guru Besar pada Fakultas Kedokteran UGM Yogyakarta.

5. Dinas Kesehatan Provinsi Sumatera Barat. Profil Kesehatan Provinsi Sumatera Barat. 2007.

6. Darmojo B, 2001. Mengamati Perjalanan Epidemiologi Hipertensi di Indonesia. Medika $7: 442-8$.

7. Kementerian Kesehatan. 2008. Laporan Nasional Riset Kesehatan Dasar (RISKESDAS) 2007. Badan Litbangkes, Depkes RI : Jakarta. Diakses di www.depkes.go.id

8. Luma GB., Spiotta RT (2006) Hypertension in Children and Adolescents.Am Fam Physician ; 73 : 1158-68.

9. Wilson P.W.F, D.Agustino R.B., Sullivan L, Parise H, Kannel W.B. 2002. Overweight and obesity as determinants of cardiovascular risk. The Framingham Experience. Arc. Intern. Med. 2, 162:1867-2.
10. Salam MA.((2010) Risiko Faktor Herediter, Obesitas dan Asupan $\mathrm{Na}$ terhadap Kejadian Hipertensi Pada Remaja Awal. Tesis. Program Studi Ilmu Gizi.Universitas Diponegoro.

11. Lipoeto NI, Fasli Jalal, Fadhil Oenzil dan Novia Susanti. 2008. Lingkar pinggang, kadar glukosa darah, trigliserida dan tekanan darah pada etnis minang di kabupaten Padang Pariaman, Sumatera Barat. M Med Indonesiana, 43(3): 129-36.

12. Aminuddin, Akbar H, Rauf S, Daud D. Risk for Developing Hypertension in Obese Adolescents, Majalah Kedokteran Indonesia. vol 53, no: 6. Juni 2003.

13. Moerdowo RM, Masalah Hipertensi (Tekanan Darah Tinggi), Bharata Karya Aksara, Jakarta 1984.

14. Mourbas Iswanelly. Hubungan Jumlah Konsumsi Makanan Terhadap Indeks Massa Tubuh Orang Dewasa di Kotamadya Padang Tahun 1996. Tesis. Program Studi Ilmu Kesehatan masyarakat. Program Pasca Sarjana Universitas Indonesia. Jakarta 1997.

15. Syahbuddin S, Konsekuensi Obesitas Terhadap Kesehatan: Fokus pada Maanfaat Klinis Penurunan Berat Badan, Subbag Endokrinologi Bagian Penyakit Dalam FKUA Padang, www.internafkunand.or.id 
16. Subarjda D, Obesitas Primer pada Anak : Diagnosis, Patogenesis dan Patofisiologi, Penerbit PT Kiblat Buku Utama, Bandung, 2004.

17. Arnow WS, Kaplan NM, Merokok. dalam Kaplan NM, Stamler J. Pencegahan penyakit jantung koroner: Penatalaksanaan praktis faktorfaktor resiko. Andrianto P. ed. EGC. Jakarta 1991.

18. McMaahon FG, Management of Essential Hypertension The New Low Dose Era, $2^{\text {nd }}$

19. Page LB. Epidemiology of Hypertension. dalam Genest J, Kuchel O, Hamet P, Cantin M. Hypertension Physiopathology and Treatment. Second edition. McGraw Hill Book Company. USA 1983.

20. Smith T, Tekanan Darah Tinggi, Arcan, Jakarta 1995.

21. Basha A, Hipertensi : Faktor Resiko dan

Penatalaksanaannya, diakses dari www. detik.com. Juli 2004.
22. Agustina, Status Gizi remaja dan faktor-faktor yang berhubungan pada siswa SMAK $V$ Kelapa Gading dan SMEA Pusaka Nusantara da Jakarta tahun 1995, Skripsi, FKM UI, Jakarta 1995.

23. Nilawati S. Peran Latihan Jasmani pada Anak Obesitas. Program Studi Ilmu Kedokteran Olahraga FKUI. dalam prosiding Simposium temu Ilmiah akbar 2002. Pusat Informasi dan Penerbitan bagian ilmu penyakit dalam FKUI. Jakarta April 2002.

24. Leon AS, Blackburn H. Ketakaktivan Fisik. dalam Kaplan NM, Stamler J. Pencegahan penyakit jantung koroner: Penatalaksanaan praktis faktorfaktor resiko. Andrianto P. ed. EGC. Jakarta 1991.

25. Arnow WS, Kaplan NM, Merokok. dalam Kaplan NM, Stamler J. Pencegahan penyakit jantung koroner : Penatalaksanaan praktis faktorfaktor resiko. Andrianto P. ed. EGC. Jakarta 1991. 